\title{
PENGGALIAN NILAI-NILAI TRADISI SINGO ULUNG SEBAGAI RELEVANSI PEMBELAJARAN
}

\author{
Septania Indri Winarni \\ Magister Pendidikan Bahasa Indonesia \\ Universitas Muhammadiyah Malang \\ taniaindri909@gmail.com
}

\begin{abstract}
ABSTRAK: Menanamkan nilai-nilai luhur bangsa Indonesia dalam lembaga pendidikan salah satunya melalui mata pelajaran Bahasa Indonesia. Disinilah bertemu antara pendidikan dan kebudayaan lokal. Pembelajaran Bahasa digunakan untuk mengkomunikasikan kearifan lokal masyarakat setempat, salah satunya Bondowoso yaitu Singo Ulung. Pembelajaran yang efektif merupakan pembelajaran yang bersifat kontekstual. Pembelajaran kontekstual yaitu hal yang dipelajari oleh peserta didik sesuai dengan kondisi nyata yang dialami oleh peserta didik itu sendiri. Peserta didik akan mudah memahami pembelajaran ketika materi pembelajaran dikaitkan langsung dengan kehidupan nyata. Peserta didik tidak mengandaiandai suatu kejadian yang ada di dalam teks.
\end{abstract}

KATA KUNCI: Kearifan Lokal, Pembelajaran, Singo Ulung.

\begin{abstract}
Instilling the noble values of the Indonesian people in educational institutions is one of them through Indonesian language subjects. This is where meeting between education and local culture. Language learning is used to communicate the local wisdom of the local community, one of which is Bondowoso, Singo Ulung. Effective learning is contextual learning. Contextual learning is things learned by students in accordance with the real conditions experienced by the students themselves. Students will easily understand learning when learning material is directly linked to real life. Students do not wish for an event in the text.
\end{abstract}

KEYWORDS: Local Wisdom, Learning, Singo Ulung.

\section{PENDAHULUAN}

Seni tradisi adalah elemen budaya yang syarat dengan kandungan-kandungan nilai luhur, dengan harapan idiom norma, etika, dan estetika di dalamnya berguna bagi perkembangan karakter personal. Seni tradisi dalam lingkup masyarakat lebih menekankan fungsi, simbol, dan makna, berkembang menurut kebudayaan yang berlaku dalam masyarakat tersebut. Menurut almarhum Profesor Umar Kayam "Seni sebagai penyangga kehidupan selalu berada di tengah-tengah kebudayaan masyarakat, karena kesenian itu sendiri merupakan wujud dari kebudayaan". Upaya yang mendasar dimana seni tradisi merupakan unsur kebudayaan yang dapat dipergunakan sebagai materi pembelajaran formal yang bermanfaat dalam pembelajaran. Kebudayaan adalah milik masyarakat yang dipergunakan bersama sebagai acuan warga masyarakat, saling bertalian guna memenuhi kebutuhan hidupnya.

Bangsa Indonesia adalah bangsa yang berdiri diatas keberagaman suku, agama, ras, etnis, bahasa, adat istiadat, tradisi, serta budaya yang disatukan dalam konsep persatuan Indonesia. Salah satu dari keberagaman tersebut adalah heterogenitas tradisi lokal yang tinggi. Setiap lokalitas tertentu memiliki perbedaan nilai-nilai kearifal lokal sesuai dengan tradisinya masing-masing. Nilainilai tradisi lokal tersebut terus tumbuh dan berkembang ke generasi selanjutnya dengan asumsi bahwa terdapat nilai-nilai kearifan, ajaran moral dan religius yang harus tetap diyakini, dijaga, dan dilestarikannya.

Menanamkan nilai-nilai luhur bangsa Indonesia dalam lembaga pendidikan salah satunya melalui mata 
pelajaran Bahasa Indonesia. Disinilah bertemu antara pendidikan dan kebudayaan lokal. Pembelajaran Bahasa digunakan untuk mengkomunikasikan kearifan lokal masyarakat setempat, salah satunya Bondowoso yaitu Singo Ulung.

Pembelajaran yang efektif merupakan pembelajaran yang bersifat kontekstual. Pembelajaran kontekstual yaitu hal yang dipelajari oleh peserta didik sesuai dengan kondisi nyata yang dialami oleh peserta didik itu sendiri. Peserta didik akan mudah memahami pembelajaran ketika materi pembelajaran dikaitkan langsung dengan kehidupan nyata. Peserta didik tidak mengandaiandai suatu kejadian yang ada di dalam teks.

\section{METODE}

Penelitian yang dilakukan merupakan penelitian tindakan kelas dalam upaya meningkatkan kemandirian belajar siswa menggunakan model dengan tradisi Singo Ulung. Pendekatan yang digunakan dalam penelitian ini adalah adalah pendekatan deskriptif. Mendeskripsikan pengamatan tentang penggunaan model pembelajaran dengan tradisi Singo Ulung.

\section{HASIL DAN PEMBAHASAN Tradisi Singo Ulung}

Setiap daerah mempunyai kebanggan tentang leluhurnya, sebab leluhur biasanya dapat memberi manfaat terhadap pembentukan identitas dan kepuasan batin. Bagi generasi penerus, warisan leluhur akan di abadikan dan di lestarikan dalam berbagai bentuk ungkapan, diantaranya dalam wujud tari tarian. Di desa Blimbing, kecamatan Klabang, terdapat tari - tarian yang berdasarkan legenda, yaitu tradisi Singo Ulung. Singo Ulung sebuah gelar terhadap seseorang yang bernama asli Juk Seng.
Singo Ulung adalah seorang bangsawan dari Blambangan Banyuwangi yang suka mengembara. Suatu saat dalam pengembaraannya kea rah barat, secara tidak sengaja memasuki hutan yang di penuhi tumbuhan belimbing. Kedatangan Singo Ulung ke hutan belantara menarik perhatian seorang tokoh yang hidup di wilayah hutan tersebu, yakni Jasiman. Sudah merupakan kebiasaan dalam masyarakat tradisional, seseorang yang di pandang tokoh meski di uji dengan berbagai tantangan dan adu kesaktian. Hal ini di maksudkan apakah tokoh tersebut mampu menjaga dirinya dengan baik. Kalau sang tokoh sendiri tidak mampu menjaga dan membela dirinya sendiri, tentu juga tidak akan mampu menjaga dan membela rakyatnya. Apalagi dalam masyarakat tradisional, seseorang pemimpin akan berwibawa dan memiliki kharisma apabila memiliki berbagai kelebihan lahir dan batin.

Melihat kedatangan Singo Ulung, Jasiman terpanggil untuk menjajal kesaktian Singo Ulung. Dengan bersenjata tongkat andalannya, Jasiman siap bertarung dengan Singo Ulung yang bersenjata keris. Tanpa basa - basi, keduanya terlibat dalam pertarungan. Kedua pendekar itu berusaha keras saling menjatuhkan lawan secepat mungkin. Tetapi karena keduanya sama - sama sakti, setelah pertarungan berjam - jam, belum tampak ada yang kalah. Tampaknya pertarungan berjalan seimbang. Keduanya lalu berhenti. Setelah itu, saling menatap dan tersenyum. Mereka lansung sepakat untuk bersahabat. Singo Ulung pun di terima berdiam di wilayah hutan.

Beberapa sesaat kemudian keduanya beristirahat dibawah sebuah pohon. Singo Ulung bertanya kepada Jasiman, " Pohon apa ini ? "Jasiman menjawab, " ini adalah pohon Belimbing." Sejak saat itu daerah hutan belantara di beri nama Belimbing. Kini 
bekas pohon yang bernilai sejarah ini dibangun sebuah sanggar yang setiap tahun di sakralkan dengan cara istigasah.

Singo Ulung dan Jasiman lalu bersepakat membangun desa sebaik mungkin. Ulung sendiri diangkat sebagai Demang yang berkuasa tunggal di desa Blimbing. Pengalaman dan kesaktian keduanya digunakan untuk berbagai kebaikan demi kemaslahatan desa Blimbing. Air yang semula sulit, berkat sebilah tongkat berhasil memancarkan air, yang lalu dapat dibuat bendungan besar di daerah itu. Dengan adanya bendungan itu, dalam waktu relatif singkat desa Blimbing menjadi subur makmur. Jasiman yang memfokuskan kerjanya sebagai ulu - ulu banyu, sudah menampakkan hasilnya. Ia berusaha mengatur air sawah secara maksimal sesuai dengan ilmu pengairan yang ia miliki.

Kesuburan dan kemakmuran membuat masyarakat Blimbing dangat percaya kepada kedua tokoh tersebut. Jasiman sebagai orang kepercayaan Singo Ulung, melaporakan suasana dan hasil yang ditanganinya secara teratur kepada Singo Ulung ditempat peristirahatannya di sanggar. Jasiman selain ahli dalam pertanian, juga sebagai guru yang mengajari murid ilmu kanuragan. Ketika mereka berada ditengah sawah, banyak murid Jasiman mengisi waktu luangnya dengan melatih keterampilan kanuragan dengan kegiatan yang di sebut " ojung ". Keterampilan ojung adalah ilmu keterampilan yang mengasah kesaktian berupa saling mencambuk dengan subuah rotan yang telah di isi dengan magis.

Bagi masyarakat Blimbing, memelihara warisan leluhur mengenang Singo Ulung di refleksikan dengan bentuk tarian Tradisi Singo Ulung. Tradisi ini dilakukan bersama upacara adat setiap tanggal 15 Sya'ban, yaitu karena purnama dilangit, menjelang bulan Ramadan. Masyarakat Blimbing sendiri sangat antusias dalam menyambut tradisi tahunan itu. Mereka menganggap sebagai bentuk penghormatan kepada nenek moyangnya yang di banggakan itu. Tak heran jika masyarakat dengan suka cita dan rela mengorbankan apa saja yang diminta, mulai dari berbagai jenis bumbu masakan sampai kepada uang. Masakan yang biasa di sediakan adalah ayam bakar, tape bakar, tape ketan putih, daging, dan sebagian dari tubuh hewan berupa telinga, bibir, dan lidah. Selain itu juga segelas kopi, nasi kuning dan kemenyan. Semuanya itu diletakkan dalam wadah yang disebut "ancak".

Dalam refleksi tarian Singo Ulung, biasanya dilakukan dua orang, satu di depan untuk menggerakkan kepala Singo Ulung dan satu lagi dibelakang sebagai kaki. Dengan iringan gamelan khas Blimbing, penampilan Singo Ulung sangat apresiatif dan atraktif.

Pementasannya dapat di klasifikasikan menjadi dua macam, yaitu pementasan Singo Ulung dalam upacara bersih desa dan pementasan Singo Ulung sebagai tontonan untuk umum. Pementasan Singo Ulung untuk bersih desa dilakukan dengan persyaratan pementasan harus dilakukan di tempat berlangsungnya upacara. Selain itu juga, waktunya harus tepat pada tanggal 15 Syaban. Demikian juga sesajennya harus lengkap, berupa nasi tumpeng, nasi rasul, biddeng gulu', lembur/degan, dudul, tetel, jenang panca warna, dan ikan 9 macam. Untuk pementasan tontonan umum tidak perlu persyaratan khusus seperti tempat, waktu dan macam makanan yang disajikan.

\section{Model Pembelajaraan Bahasa Indo Berbasis Nilai-Nilai Tradisi Singo Ulung \\ Sebelum kita membicarakan} bagaimana desain model pembelajaran Bahasa Indonesia berbasis nilai-nilai tradisi Singo Ulung alangkah baikknya jika mengetahui konsep dari desain model 
pembelajaran itu sendiri. Gustafson dan Branch bahwa desain pembelajaran merupakan proses sistematis yang digunakan untuk mengembangkan program pendidikan dan pelatihan. Desain pembelajaran adalah proses sistematis yang digunakan untuk mengembangkan program-program pendidikan dan pelatihan secara konsisten dan dapat diandalkan. Desain pembelajaran adalah proses yang kompleks yang kreatif, aktif, dan interaktif.

Dalam literatur-literatur bahasa Ingris, desain pembelajaran dikenal dengan istilah Instructional Design. Herbert Simon mengartikan desain sebagai proses pemecahan masalah. Tujuan sebuah desain adalah untuk mencapai solusi terbaik dalam memecahkan masalah dengan memanfaatkan sejumlah informasi yang tersedia. Dengan demikian, suatu desain muncul karena kebutuhan manusia untuk memecahkan suatu persoalan. Sehingga, pada dasarnya desain adalah suatu proses yang bersifat linear yang diawali dari penentuan kebutuhan, kemudian mengembangkan rancangan untuk merespon kebutuhan tersebut, selanjutnya rancangan tersebut diujicobakan dan akhirnya dilakukan proses evaluasi untuk menentukan hasil tentang efektivitas rancangan (desain) yang disusun.

Gagne menjelaskan bahwa desain pembelajaran disusun untuk membantu proses belajar peserta didik, dimana proses belajar itu memilki tahapan segera dan tahapan jangka panjang. Menurut Gagne belajar sesorang dipengaruhi oleh faktor internal dan eksternal. Faktor internal berkaitan dengan kondisi yang dibawa atau yang datang dari individu, seperti kemampuan dasar, gaya belajar, minat dan bakat, serta kesiapan peserta didik untuk mengikuti pembelajaran. Faktor eksternal adalah faktor yang datang dari luar individu, yakni berkaitan dengan penyedian kondisi atau lingkungan yang didesain agar peserta didik belajar. Menurut Gagne, kondisi internal dapat dibangkitkan oleh aturan kondisi eksternal.

Dari pengertian diatas, dapat disimpulkan bahwa desain pembelajaran berkenaan dengan proses pembelajaran yang dapat dialakukan peserta didik untuk mempelajari suatu materi pelajaran yang di dalamnya mencakup rumusan tujuan yang harus dicapai atau hasil belajar yang diharapkan, rumusan strategi yang dapat dilaksanakan untuk mencapai tujuan termasuk metode, teknik dan media yang dapat dimanfaatkan serta teknik evaluasi untuk mengukur atau menentukan keberhasilan pencapaian tujuan.

Mengacu pada konsep Borg dan Gall (1983, hlm. 774-775), bahwa langkah pengembangan model pembelajaran dapat dimodifikasi oleh peneliti sesuai dengan tujuan yang ingin dicapai oleh peneliti. Dalam buku ini, pengembangan model pembelajaran sejarah berbasis nilai-nilai tradisi Singo Ulung mengadobsi model desain pembelajaran ADDIE. Adapun langkahlangkah pengembangan desain pembelajaran ADDIE yang peneliti gunakan, yaitu: (1) analisis kebutuhan; (2) desain model; (3) pengembangan model; (4) implementasi model; dan (5) evaluasi. Kelima tahap tersebut secara garis besar juga dapat disederhanakan menjadi tiga tahapan yaitu : (1) hasil studi pendahuluan; (2) pengembangan model pembelajaran; (3) uji efektifitas model pembelajaran (lihat lampiran).

Model ADDIE adalah desain pembelajaran yang dapat memfasilitasi peserta didik dalam mengembangkan proses sains, bersifat kooperatif, fleksibel, menyesuaikan dengan lingkungan belajar yang berorientasikan pada struktur implementasi. Pandangan teori konstruktivis dalam tentang desain 
FON : Jurnal Pendidikan Bahasa dan Sastra Indonesia

Volume 15 Nomor 2 Tahun 2019

sistem pengajaran sering dinyatakan melalui model pembelajaran ADDIE. Metode pengajaran yang dilaksanakan dalam model ADDIE meliputi melaksanakan studi kasus, diskusi pemikiran kritis, pembelajaran berbasis masalah, proyek laboratorium, dan inquiri terbimbing.

Penjelasan singkat Model ADDIE yang terdiri dari lima komponen atau langkah tersebut adaah sebagai berikut :

\section{a) Analisis (Analysis)}

Analisis dilakukan untuk menentukan kebutuhan belajar, apa yang akan diajarkan, dan kompetensi apa yang diharapkan dikuasai peserta didik setelah belajar.

\section{b) Desain (Design)}

Setelah kebutuhan belajar diidentifikasi, langkah berikutnya adalah mendesain pembelajaran. Kegiata $n$ yang dilakukan pada tahap desain meliputi: merumuskan kompetensi (tujuan pembelajaran khusus); menentukan materi pembelajaran, strategi, media, evaluasi, dan sumber.

\section{c) Pengembangan (Develop)}

Langkah pengembangan berupa memproduksi atau membuat atau mewujudkan spesifikasi pembelajaran yang telah ditentukan pada tahap desain. Jika pada tahap desain ditentukan bahwa dalam pembelajaran akan digunakan video, maka kegiatan pada tahap pengembangan ini adalah memproduksi video (jika belum tersedia), atau memilih, membeli, meminjam jika telah tersedia di sekolah.

\section{d) Implementasi (Implement)}

Setelah paket pembelajaran dikembangkan pada tahap 3, langkah berikutnya adalah memanfaatkan atau menggunakan paket pembelajaran tersebut dalam kegiatan pembelajaran. Kegiatan yang perlu dipersiapkan antara lain jadwal, penyiapan ruang kelas, alat dan media, meyiapkan peserta didik secara fisik maupun mental.

\section{Nilai-Nilai Kearifan Lokal (Gotong Royong) dalam Tradisi Singo Ulung}

Tradisi Singo Ulung yang ada di desa Blimbing, Kecamatan Klabang, Kabupaten Bondwososo merupakan representatif salah satu dari tradisi budaya lokal yang ada di Indonesia. Tradisi ini memuat nilai spritual dan sosial budaya. Nilai spritual yaitu: (1) diadakannya selamatan yang memuat sesaji, mitos, dan seni spritual sebagai simbolik rasa syukur kepada Tuhan; (2) penghormatan kepada arwah leluhur yang mereka yakini guna mencari keselamatan hidup lahir dan batin. Acara selamatan tersebut merupakan akulturasi dari kebudayaan zaman Hindu-Budha (kepercayaan animisme dan dinamisme) dan Islam yang masih diyakini dan dipertahankan hingga sekarang.

Tujuan utama dari proses dari tradisi Singo Ulung bukan hanya sekedar formalitas ritual tahunan. Tradisi ini memiliki bobot spiritual sebagai wahana untuk : (1) menyatakan syukur kepada Tuhan atas ketentraman penduduk desa dan hasil panennya; (2) memberi penghormatan kepada para leluhur dan penghormatan kepada arwah paraleluhur; (3) mengharapkan pengayoman (nyuwun wilujeng) dari Tuhan.

Nilai sosial budaya dalam tradisi Singo Ulung yaitu terjadinya integrasi sosial di dalam pelaksanaan tradisi 
FON : Jurnal Pendidikan Bahasa dan Sastra Indonesia

Volume 15 Nomor 2 Tahun 2019

tersebut, dimana dalam proses pelaksanaan melibatkan seluruh warga desa tersebut. Keterlibatan warga tersebut akan mewujudkan komunikasi sosial, solidaritas sosial, dan sikap gotong royong antar satu warga dengan warga lainnya. Tradisi tersebut pada umumnya menjadi hajatan besar, dimana semua warga akan berkumpul dan saling tolong- menolong dalam mempersiapkan acara selamatan tersebut. Hal ini sejalan dengan pendapat Brown bahwa ritual dan adat istiadat dapat berlansung terus karena memiliki fungsi sosial. Dengan begitu, maka suatu tradisi akan berjalan terus-menerus apabila didukung oleh seluruh komponen masyarakat sekitarnya.

Secara sosial tradisi Singo Ulung juga sebagai forum interaktif antarwarga masyarakat yang pada gilirannya akan membangun solidaritas sosial, komunikasi sosial, dan sikap gotong royong. Komunikasi sosial budaya ini sudah barang tentu mempunyai dampak positif bagi kelangsungan kehidupan bermasyarakat.

Menurut Endraswara suatu tradisi yang merupakan hajatan besar dari setiap lokalitas pasti memakan biaya besar dan curahan tenaga masyrakat desa yang tidak terkirakan. Adapun manfaatnya antara lain adalah: (1) mendekatkan diri masyarakat dengan Tuhan Maha Esa; (2) untuk meningkatkan rasa hormat kepada Rasulullah dan mengindahkan tuntunannya; (3) meningkatkan kecintaan masyarakat kepada desanya, daerah, dan tanah air; (4) memperat keguyuban (tali persaudaran atau gotong royong) antar warga desa; (5) untuk mematangkan diri dalam bercocok tanam dan usaha; (6) meningkatkan kesadaran masayarakat desa untuk melestarikan lingkungannya serta budayanya.

Masyarakat Kabupaten

Bondowoso bagian utara (Desa Blimbing) mayoritas menggantungkan hidupnya pada bidang pertanian (agraris).
Masyarakat agraris cenderung mempertahankan budaya dan adat istiadatnya. Salah satu tradisi masyarakat petani di Bondowoso dalam bidang pertanian, yaitu setiap tahunnya secara rutin melakukan tradisi Singo Ulung dengan tujuan membersihkan desa dari marabahaya, sekaligus sebagai ungkapan ucapan syukur kepada Tuhan, serta arwah nenek moyang atas perlindungan dan pemberian rezeki berupa hasil pertanian. Keadaan geografis suatu daerah pada umumnya juga turut mengakibatkan tumbuh suburnya tradisi yang ada di Indonesia.

Kabupaten Bondowoso pada umumnya terdiri dari beberapa etnis, yaitu Madura, Jawa, Cina, dan Arab. Etnis Madura merupakan etnis pendatang dari Pulau Madura yang melakukan migrasi ke daerah Bondowoso. Etnis Jawa di Kabupaten Bondowoso pada hakekatnya yaitu terbagi menjadi dua, yaitu etnis Jawa asli dan pendatang. Etnis Jawa asli adalah penduduk yang sudah berdiam dan bertempat tinggal jauh sebelum etnis Madura dan Jawa (pendatang) datang. Etnis Jawa pendatang adalah etnis Jawa yang datang pada masa pembukaan perkebunan Hindia Belanda. Sedangkan etnis Cina dan Arab merupakan etnis minoritas di Kabupaten Bondowoso.

Masyarakat desa Blimbing mayoritas merupakan pemeluk agama Islam dan etnis Madura. Walaupun mayoritas adalah pemeluk agama Islam tetapi sebagai besar masyarakat ternyata masih mewarisi kepercayaan pra-Islam, yaitu kepercayaan terhadap hal-hal yang bersifat gaib atau roh-roh halus sehingga masyarakat yang bersifat sinkretis (penyatuan unsur-unsur pra Hindu).

Hindu, dan Islam. Tradisi tersebut biasanya dilakukan setiap tanggal 13, 14, dan 15 Sya'ban. Tradisi Singo Ulung di desa Blimbing memiliki ciri yang khas dari segi prosesi pelaksanaannya, yaitu menggunakan tarian Singo Ulung sebagai 
FON : Jurnal Pendidikan Bahasa dan Sastra Indonesia

Volume 15 Nomor 2 Tahun 2019

media dan sarana komunikasi kepada arwah leluhur yang dihormati dan diyakini. Tradisi tarian Singo Ulung Blimbing merupakan perwujudan pernghormatan kepada tokoh pembabat desa Blimbing, yaitu Juk Seng dan Juk Jasiman yang dipercaya dapat memberikan perlindungan terhadap masyarakat yang ada di desa Blimbing. Pada dasarnya tujuan ritual tersebut yaitu mencari kesalamatan hidup dan bersyukur kepada Tuhan atas hasil panen (rejeki) yang diperoleh, serta untuk melindungi desa dari segala macam marabahaya yang akan menimpa masyarakat. Tujuan tersebut pada prinsipnya hampir sama dengan tradisi lainnya yang ada di Jawa. Hanya saja prosesi, media dan sarana yang digunakan berbeda-beda sesuai dengan budaya, tradisi, serta keyakinan setiap masyarakatnya.

Tradisi Singo Ulung masyarakat Blimbing yang diadakan setiap tanggal 13, 14, 15 Sya'ban merupakan upacara ritual yang disakralkan. Oleh karena itu, semua warga masyarakat Blimbing diwajibkan untuk ikut serta. Semua lapisan masyarakat ikut terlibat aktif dalam acara sakral tersebut, mulai dari tokoh masyarakat (kepala desa), pawang atau pimpinan upacara, juru masak, masyarakat desa Blimbing, serta para pemain pertujukan kesenian, bahkan sering terjadi warga tetangga desa ikut serta meramaikannya. Tradisi ini merupakan hajatan besar dan memakan biaya yang tidak sedikit pula. Maka dari itu, semua elemen masyarakat desa Blimbing harus secara sadar saling tolong-menolong dalam meringankan beban tersebut. Sikap gotong royong tersebut nampak dalam bagaimana mempersipkan upacara ritual tersebut, mulai dari rapat desa, penyembelihan hewan kurban, sesoklon, Rokat Sanggher, Rokat Taneyan, Rokal Talang, Rokat Astah, pentas kesenian hiburan, Rokat Bendhung
Naggher, dan yang terakhir yaitu pertujukan sakral Singo Ulung.

Ketika prosesi pelaksanaan tradisi tersebut, masyarakat secara sukarela dan gotong royong ikut meramaikan dan mensukseskan acara ini dengan anggapan bahwa itu merupakan kewajiban dan kebutuhan bersama. Sikap gotong-royong diantara sesama masyarakat tersebut terjalin dengan baik karena adanya komunikasi sosial yang baik pula. Komunikasi sosial yang terjalin baik diantara masyarakat desa Blimbing itu mampu membangun dan meningkatkan sikap gotong royong yang semakin hilang ditelan oleh era globalisasi.

Berdasarkan penjelasan di atas, maka model pembelajaran sejarah berbasis nilai-nilai tradisi Singo Ulung di desa Blimbing dimaksudkan memberikan pemahaman kepada peserta didik dalam mengkaji sejarah sesuai dengan Standar Kompetensi dan Kompetensi Dasar yang ada, khususnya pada Standar Kompetensi menganalisis perjalanan bangsa Indonesia pada masa negara-negara tradisional dan Kompetensi Dasar tentang perkembangan kebudayaan Hindu-Budha dan Islam serta peninggalannya. Salah satu bentuk dari peninggalan kebudayaan tersebut adalah tradisi Singo Ulung, yang merupakan akulturasi dari kebudayaan animisme, dinamisme, Hindu, Budha, dan ajaran Islam. Sementara itu, komunikasi yang terjadi pada masyarakat desa Bimbing (Jawa, Madura, Arab, dan Cina) tanpa melihat perbedaan SARA tersebut dapat dijadikan contoh untuk meningkatkan sikap gotong peserta didik di SMAN Grujugan. Dengan demikian, diharapkan peserta didik tidak hanya memiliki kompetensi akademik (kognitif) saja, namum juga memiliki kompetensi sosial (afektif) dalam kehidupan berbangsa dan bernegara. 
FON : Jurnal Pendidikan Bahasa dan Sastra Indonesia

Volume 15 Nomor 2 Tahun 2019

Pelaksanaan Pembelajaran Bahasa Indonesia Berbasis Nilai-Nilai Tradisi Singo Ulung

Pembelajaran Bahasa Indonesia berbasis nilai-nilai tradisi Singo Ulung berupaya mengintegrasikan strategi Group Investigation dan Value Clarification Technique untuk meningkatkan kompetensi akademik dan sosial peserta didik. Adapun komponen dari desain model pembelajaran sejarah berbasis nilainilai tradisi Singo Ulung sebagai berikut : (1) langkah-langkah pembelajaran (sintax); (2) sistem sosial; (3) prinsip reaksi; (4) sistem pendukung; dan (5) dampak instruksional dan pengiring. Selain itu, model ini juga memiliki beberapa komponen lainnya yaitu : (1) standar kompetensi; (2) kompetensi dasar; (3) tujuan pembelajaran; (4) materi pembelajaran; dan (5) rencana pelaksanaan pembelajaran (lihat lampiran).

\section{KESIMPULAN}

Menanamkan nilai-nilai luhur bangsa Indonesia dalam lembaga pendidikan salah satunya melalui mata pelajaran Bahasa Indonesia. Disinilah bertemu antara pendidikan dan kebudayaan lokal. Pembelajaran Bahasa digunakan untuk mengkomunikasikan kearifan lokal masyarakat setempat, salah satunya Bondowoso yaitu Singo Ulung. Nilai yang terdapat dalam tradisi Singo Ulung yang berupa gotong royong dalam diaplikasikan dalam pembelajaran.

Pembelajaran yang efektif merupakan pembelajaran yang bersifat kontekstual.
Pembelajaran kontekstual yaitu hal yang dipelajari oleh peserta didik sesuai dengan kondisi nyata yang dialami oleh peserta didik itu sendiri. Peserta didik akan mudah memahami pembelajaran ketika materi pembelajaran dikaitkan langsung dengan kehidupan nyata. Peserta didik tidak mengandai-andai suatu kejadian yang ada di dalam teks.

\section{DAFTAR PUSTAKA}

Adisusilo, S. (2014). Pembelajaran Nilai Karakter: Konstruktivisme dan VCT Sebagai Inovasi Pendekatan Pemebelajaran Afektif. Jakarta: PT Raja Grafindo Persada.

Calhoun, Joyce, dan Weil. Model of Teaching: Model-Model Pengajaran: Edisi Kedelapan. Yogyakarta : Pustaka Pelajar.

\begin{tabular}{|c|c|c|c|}
\hline \multirow[t]{3}{*}{ Gafur, } & \multicolumn{2}{|c|}{$\begin{array}{c}\text { A. } \quad(2012) \text {. } \\
\text { Pembelajaran:Konsep, }\end{array}$} & $\begin{array}{l}\text { Desain } \\
\text { Model, }\end{array}$ \\
\hline & dan & Aplikasinya & Dalam \\
\hline & $\begin{array}{l}\text { Perenca } \\
\text { Pembela } \\
\text { Ombak. }\end{array}$ & $\begin{array}{l}\text { naan } \\
\text { jaran. }\end{array}$ & $\begin{array}{l}\text { Pelaksanaan } \\
\text { Yogyakarta: }\end{array}$ \\
\hline
\end{tabular}

Mulyana, R. (2011). Mengartikulasikan Pendidikan Nilai. Bandung: Alfabeta.

Endraswara, S. (2006). Kejawen. Jurnal Kebudayaan Jawa Fakultas Bahasa Seni Universitas Negeri Yogyakarta.Vol. 1, hlm. 56.

Kristanti, L.D. (2011). Dinamika Kesenian Singo Ulung Di Kabupaten Bondowoso Tahun (1942-2011). Tidak Diterbitkan. Skripsi. Jember:Universitas Jember. 